\title{
«EL AGUADOR» DE VELÁZQUEZ O UNA MEDITACIÓN SOBRE LA CULTURA CLÁSICA: «DIÓGENES Y LOS HIJOS DE XENÍADES»
}

\author{
POR \\ MANUELA B. MENA MARQUÉS \\ Museo del Prado
}

Considered traditionally as the best example of Velázquez early «pintura de bodegones», or genre and still life The Water-seller is presented here as a clear representation of the Greek philosopher Diogenes, in his most essential role of mentor of youth. Based on texts of Diogenes Laertius, well known in Spain at the time, Velázquez painted it for Juan de Fonseca, canon «maestrescuela» of Seville Cathedral.

$=6$

A don Diego Angulo Iñiguez, in memoriam

\begin{abstract}
«Diego Velázquez queda acreditado con sólo nombrarlo. En Sevilla aprendió a hacer las grandes obras que aplaudió el mundo. Fue erudito y Filósofo, y después de las luces que adquirió en la carrera de las letras ejercitó filosóficamente la Pintura, habiendo llegado a conocer el natural como ninguno».
\end{abstract}

(Antonio Ponz, Viaje de España, 1772-94, vol. IX, ix 4.)

En 1948, don Diego Angulo Iñiguez identificó el asunto de Las hilanderas de Velázquez en un artículo brillante ${ }^{1}$ que descartaba, de una vez por todas, la bien asentada idea de que el lienzo era una simple representación del natural, haciendo ver que lo pintado por el artista no era lo que parecía, una escena de obreras de la tapicería real de Santa Isabel, sino la famosa contienda entre la diosa Minerva y la mortal Aracné, según las Metamorfosis de Ovidio.

1 D. Angulo Iñiguez, «Las Hilanderas», Archivo Español de Arte, 1948, n. ${ }^{\circ} 81$, pp. 1-19. Ya Enriqueta Harris, en una publicación anterior, The Prado, Londres, 1940, p. 85, adelantaba la posibilidad de que las figuras del fondo fueron Minerva y Aracné. Por otro lado, Ortega y Gasset, había entrevisto la posibilidad de que la obra se refiriera a un tema clásico y había apuntado poco antes que pudiera tratarse de Las Parcas el grupo de tres figuras femeninas del primer término: Ortega y Gasset, Velázquez, 1943, citado por la ed. de 1987, p. 49. Finalmente la excelente labor de archivo de María Luisa Caturla dio como resultado la identificación de quien debió de ser el primer propietario de la obra, don Pedro de Arce, en cuya colección figuraba en 1664 según un documento de tasación de sus bienes: Otra pintura de diego Belazquez de la Fabula de Aragne, de mas de tres baras de largo y dos de cayda, tasada en quinientos ducados, en «El coleccionista madrileño don Pedro de Arce, que poseyó 'Las Hilanderas' de Velázquez», Archivo Español de Arte, 1948, n. ${ }^{\circ}$ 50, p. 292-304. 
Después de Los borrachos, «una pintura de Baco» ${ }^{2}$, del Marte para la Torre de la Parada, de la Venus del espejo y de Mercurio y Argos, única composición conservada de las cuatro de tema mitológico que decoraron las sobrepuertas del Salón Grande o Salón de los Espejos del Alcázar, Las Hilanderas recuperaban por fin su sentido original, basado en un mito clásico. El ambiente cortesano parecía justificar, para muchos, que Velázquez se hubiera visto obligado a torcer la natural inclinación de su juventud hacia la pintura de bodegones, teniendo que pintar en su vida obras de asunto mitológico. Los trabajos para el rey o para personajes cultos como don Pedro de Arce, propietario de Las hilanderas ${ }^{3}$, venían así compensados con creces a los ojos de quienes trataron a Velázquez como un simple pintor de la realidad, con los «informales» retratos de enanos y bufones ${ }^{4} \mathrm{o}$ con esa famosa Cuerna de venado que citaba Ponz en el siglo XVIII, cuando ya alterada por pintores mediocres había sufrido los añadidos que desvirtúan su extraña y desnuda belleza original: «Por de Velázquez se estima un quadro que hay un búho pintado y varias cabezas de caza muerta» ${ }^{5}$.

Quedaban para esos admiradores de un Velázquez entendido como gloria de ese realismo español profundo y autóctono, los lienzos de su juventud sevillana: los famosos bodegones y mesas servidas, citadas por las fuentes como de su mano. Como ejemplo supremo de ese primer naturalismo del artista, entendido, desde luego erróneamente, como copia directa de la vida cotidiana sin mayor elaboración, se ha puesto siempre a El Aguador (Fig. 1), titulado además de un modo costumbrista, y hasta gracioso si se quiere, como El Aguador de Sevilla. Justi, en su monumental estudio sobre Velázquez, fue quien primero sentó las bases modernas, que se han mantenido sin apenas variantes hasta nuestros días, de la apreciación de esta obra como ejemplo de inspiración en la realidad, unido además a sutiles factores nacionalistas: «Así hace su aparición en esta primera figura de Velázquez un rasgo característico de gran importancia que, a partir de este momento, se va a repetir, a modo de certificado de garantía, en todas las que realice. Se trata del peso que adquiere el porte, el aplomo en su matiz específicamente español, como una mezcla de temperamento y orgullo de clase, de raza, de flema y dignidad personal» ${ }^{6}$. Incluso una obra reciente, de carácter monográfico, sobre la pintura de «bodegones» de Velázquez, el bien documentado estudio de Barry Wind, no se despega del tópico español cuando, como Justi cien años antes, afirma: "The water carrier, his weathered face ravaged by the unrelenting Sevillian sun, stands in hieratic profile dominating the painting ${ }^{7}$. Bien es verdad que ya el inventario de la colección real de 1700 se refería al cuadro, casi ochenta años después de que fuera pintado y cuarenta

2 Descrito en la orden de pago de Felipe IV a Velázquez, de 22 de julio de 1629, en que se le pagaron 100 escudos por esta composición, en Velázquez. Homenaje en el Tercer Centenario de su muerte, Instituto Diego Velázquez, C.S.I.C., 1960, p. 253. (Cito por esta cómoda y excelente publicación, pocas veces mencionada en la bibliografía velazqueña, que fue editada por el Insituto Diego Velázquez y dirigida por don Diego Angulo Iñiguez).

3 M.L. Caturla, op. cit., 1948, reunió los pocos datos que se conocen sobre don Pedro de Arce.

4 Para nueva identificación del conjunto de los enanos de Velázquez y de sus obras en la Torre de la Parada, ver, Manuela B. Mena Marqués, «Velázquez en la Torre de la Parada», texto de la conferencia impartida en la Academia de la Historia, Madrid, 9 de noviembre de 1999 (en prensa en edición de la Academia de la Historia; prevista su aparición a principios del 2000).

5 Antonio Ponz, Viaje de España, ed. 1947, p. 561.

6 Carl Justi, Velázquez y su siglo, 1888, ed. española, Madrid, 1999, p. 141.

7 Traducción: "El Aguador, con su rostro curtido, endurecido por el sol implacable de Sevilla, está en pie, dominando todo el cuadro con su hierático perfil»: Barry Wind, Velázquez Bodegones. A Study in SeventeenthCentury Spanish Genre Painting, The George Mason University Press, 1987, p. 25. 


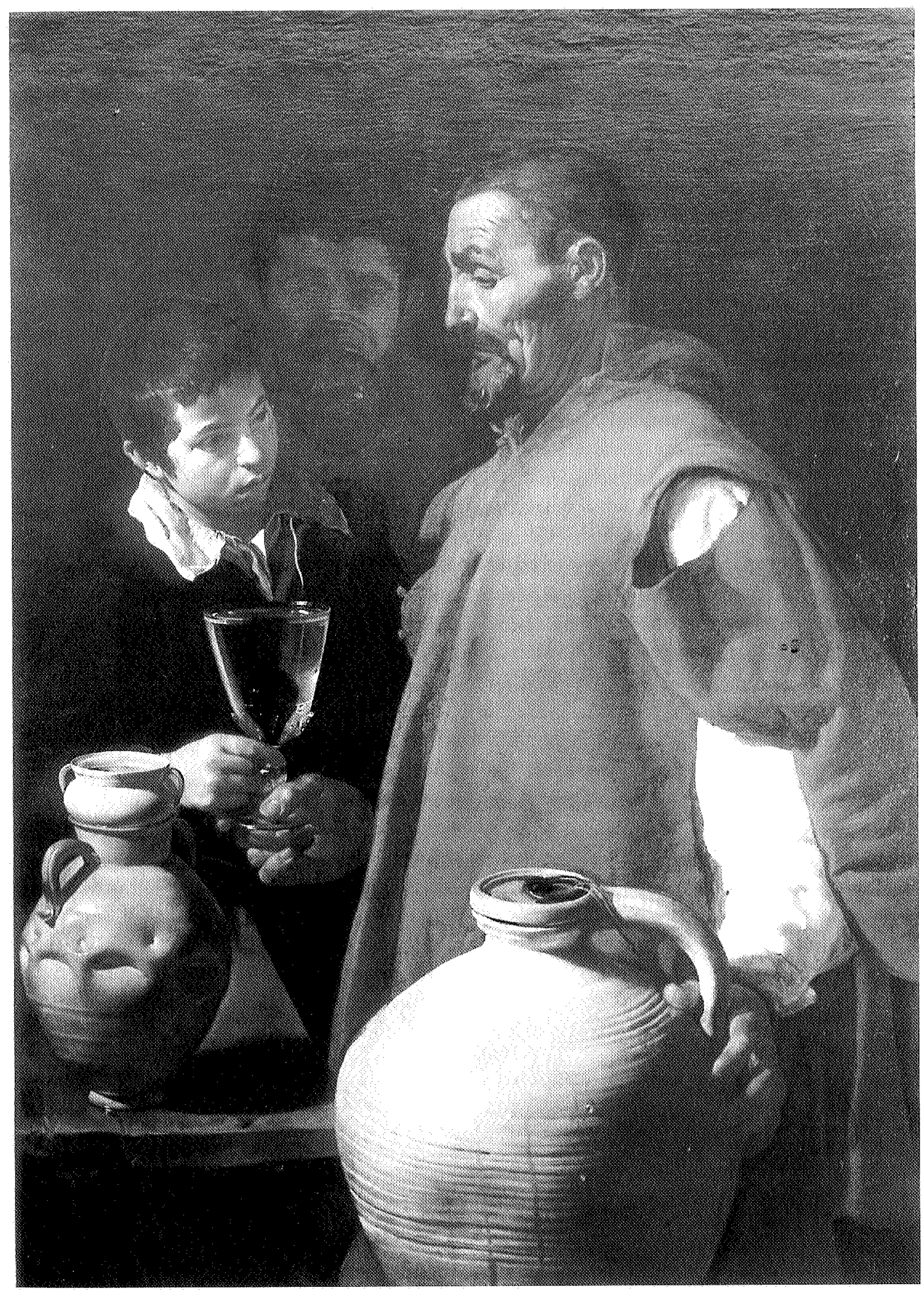

Figura 1. Velázquez: El Aguador. Londres. Wellington Museum (Apsley House). Reproducido con permiso de The Board of Trustees of the Victoria Albert Museum. 
después de la muerte de Velázquez, como «..un rettrato de un Aguador de mano de Velázquez, llamado el dh aguador el corzo de Sevilla con marco dorado y negro, tassado en diez doblones» ${ }^{8}$, dando lugar a una tradición que ha insistido en el fácil recurso a la inspiración en la realidad concreta, como si Velázquez hubiera hecho en El Aguador una transposición de las escenas de vendedores callejeros del boloñés Annibale Carracci, fechadas a principios del siglo XVII ${ }^{9}$. Las Arti di Bologna, del pintor italiano, presentaban figuras de vendedores callejeros (figs. 2 y 3 ) voceando y vendiendo sus mercancías de un modo ruidoso, bien lejano del silencio voluntario, casi conventual, que emana del "aguador" velazqueño, que no parece, además, traficar con su mercancía sino impartirla como un sacramento.

Poco después de la cita en los inventarios reales, Palomino mencionaba el lienzo, con todos los honores, en su biografía de Velázquez, incluido precisamente entre las pinturas de bodegones. Lo debía de haber visto rápidamente, como de pasada, o lo confundía en su memoria con algún otro, quizá de Ribera, pues lo describía con notables cambios respecto de la pintura original, que reforzaban precisamente su aspecto más naturalista y vulgar de copia fiel de la realidad: «...no se nos debe pasar en silencio la Pintura que llaman del Aguador; el qual es un viejo muy mal vestido y con un sayo vil y roto, que se le descubría el pecho, y vientre con las costras, y callos duros, y fuertes, y junto a sí tiene un muchacho a quien da de beber» ${ }^{10}$. Es cierto, por otra parte, que El Aguador está documentado desde 1627, cuando se registró por primera vez en el inventario de los bienes de don Juan de Fonseca, muerto el 15 de enero de ese año ${ }^{11}$. En su casa madrileña y entre otras obras de su colección, figuraba el cuadro, que fue tasado con los demás, a petición de los albaceas por Velázquez, pintor del rey. Se describe, que no titula, en ese inventario de modo sumario por los mismos escribanos que lo redactaron: «Un quadro de un aguador, de mano de Diego Velazquez, quatrocientos $r l s . . . . . .400 »{ }^{12}$. Es curioso subrayar que de las cerca de cien pinturas registradas en el inventario de Fonseca, aparte de la de Velázquez, sólo otras cinco, unas Historias de Jacob y Un Christo y San Juan en el baptismo, presentan nombre de autor, siendo atribuidas a Orrente ${ }^{13}$. Tal vez el resto no fueran cuadros de buena calidad, y por tanto difícil el darles nombre, o tal vez Velázquez no reconoció a los autores de las obras. Sólo añade el suyo y bien deletreado, tasando, además, su cuadro en el precio más alto de todos, en 400 reales, pues era seguramente el de mejor calidad.

Puede que el nombre de Velázquez en el lote de El Aguador del inventario de las pinturas de Fonseca se añadiera incluso después de redactado el mismo, lo que se llevó a cabo entre el 16 y el 21 de enero, y ya cuando el día 28 de ese mismo mes las vio y tasó el artista. En el mismo documento, al principio, cuando los testamentarios disponen que la parte de pinturas la tase Velázquez, y también después, en el documento resultante de la almoneda pública de los citados bienes, el nombre del artista se escribe incorrectamente como Belazquez, con una ortografía frecuente en los documentos de esos años que citan al pintor. En la descripción de su cuadro en el inventario, su nombre aparece, sin embargo, correctamente escrito, como si él mismo lo hubiera deletreado ante el escribano o éste lo hubiera copiado de la firma que es-

8 Testamentaria del rey Carlos II, edición de Gloria Fernández Bayton, Madrid, Museo del Prado, 1981, vol. II, p. 216, n. $^{\circ} 496$.

9 Le Arti di Bologna, editado por Alessandro Marabottini, Roma, 1966 y 1979.

10 Antonio Acisclo Palomino, El Museo Pictórico y Escala Óptica (1715-1724), ed. 1947, p. 893.

1 José López Navío, «Velázquez tasa los cuadros de su protector D. Juan de Fonseca», Archivo Español de Arte, 1961, n. ${ }^{\circ} 34$, pp. 53-84.

12 José López Navío, op, cit. 1961, p. 64.

13 Quizá se refiera también a un artista la inscripción que aparece en uno de los registros del inventario, «Un San Joseph en tabla, del seran....165». Si se piensa que Fonseca había sido embajador en Parma, quizá adquirió allí alguna de las obras de su colección. Tal vez ese «seran», sea una mala transcripción, de oídas, del nombre que dictara Velázquez, quizá el de «il Cerano», artista del norte de Italia, muy admirado en España. 
tampó el pintor en el documento de tasación. Velázquez, en el único día que tuvo para tasar las cerca de cien pinturas que formaban la colección de su protector, no se molestó en aclarar la descripción de los escribanos de su cuadro, hecha unos días antes, porque era correcta. Les hizo completar, tal vez, su autoría, que indudablemente le importaba mucho, pero aceptó sin más cambios lo que figuraba ya escrito por aquéllos, pues esa rápida y superficial descripción de la obra como un aguador, la hacía evidente y directa, como hasta nuestros días, y de mayor impacto para quienes asistieran a la almoneda que se iba a celebrar unos días después ${ }^{14}$.

El Aguador se convertía así, en lo que se entendió por mano del propio Velázquez, en una pintura exclusivamente de género. Los historiadores de nuestro siglo y especialmente aquéllos que trabajaron después de la publicación, en 1961, del documento de la colección de Fonseca, cegados por el nombre de ese Velázquez tasador de su propia obra, no supieron ver un posible asunto de otro carácter más allá de la copia de la realidad cotidiana y, en este caso, además, sevillana. Realidad que atestiguaban, además, en esta ocasión los mencionados inventarios, tanto el de Fonseca, como el de la colección real, que daba, además, nombre al austero protagonista de la acción. Así, López Rey, consagraba en su monografía velazqueña la leyenda de un aguador «corzo» o «córso» de los inventarios reales, fundiéndola con el error de Palomino al describir el lienzo y sugiriendo novelescamente que la fama de un aguerrido aguador sevillano o corso, de pecho descubierto y callos duros, flotaba aun en las tertulias del viejo Alcázar, cuando se admiraba el cuadro de Velázquez ${ }^{15}$.

Hasta nuestros días, el cuadro se ha seguido viendo ya como una simple escena de género, como uno más de esos «bodegones» descritos por Pacheco en el famoso párrafo de su libro que parecía destinado a justificar, con la imitación de artistas de la Antigüedad, las veleidades por la naturaleza muerta y por «las cosas humildes» de su queridö̌ y admirado yerno: ¿¿Pues qué? ¿Los bodegones no se deben estimar? Claro está que sí, si son pintados como mi yerno los pinta alzándose con esta parte sin dexar lugar a otro, y merecen estimación grandísima; pues con estos principios y los retratos, de que hablaremos luego, halló la verdadera imitación del natural, alentando los ánimos de muchos con su poderoso exemplo...... Cuando las figuras tienen valentía, debuxo y colorido, y parecen vivas, y son iguales a las demás cosas del natural que se juntan en estas pinturas, que habemos dicho, traen sumo honor al artífice» ${ }^{16}$. Es cierto que Pacheco se refería a Velázquez como autor de bodegones, pero es cierto también que entre los que se han considerado «bodegones» del pintor se han incluido obras como el Cristo en casa de Marta y María o La cena de Emaús, conocido como La mulata, de tema religioso y moralizante. Citados y reproducidos exhaustivamente en la bibliografía velazqueña, se han incluido además en recientes exposiciones monográficas sobre la naturaleza muerta española ${ }^{17}$ como paradigmas del género, aunque formen una

14 El Aguador fue adquirido en la almoneda de los bienes de Fonseca por D. Gaspar de Bracamonte en 330 reales, testamentario del canónigo y camarero del infante-cardenal don Fernando. Se lo vendió, al parecer, al infante o se la regaló y quedó en la colección real, tal vez en el palacio del Buen Retiro, donde se menciona por prìmera vez en el inventario de 1700 .

15 José López Rey, Velázquez. A Catalogue Raisonné of His Oeuvre, Londres 1963, p. 123, n. ${ }^{\circ} 124$ y del mismo autor, Velázquez. The Artist as a Maker, París, 1979, p. 213, n. ${ }^{\circ} 16$.

16 Francisco Pacheco, Arte de la Pintura (1649), ed. 1990, p. 519.

17 Ulrich Nefzger, «Wirklichkeit, Wahrheit und Würde bei Velázquez», Pantheon, 1997, pp. 75-91. A.E. Pérez Sánchez, Pintura española de bodegones y floreros de 1600 a Goya, Madrid, Museo del Prado, 1983-84; Cristo en casa de Marta y María junto a La mulata (Cena de Emaús) y La vieja friendo huevos en William Jordan, Spanish Still Life in the Golden Age, 1600-1650, Kimbell Art Museum, en 1985; La vieja friendo huevos, El Aguador y Cristo en casa de Marta y María, en William Jordan y Peter Cherry, Spanish Still Life from Velázquez, to Goya, Londres, The National Gallery, 1995. 
evidente categoría aparte. Desde un punto de vista puramente visual y compositivo, que no ya iconográfico, destacan estas obras y se apartan por completo del género conocido en España por pintura de «bodegones» ${ }^{18}$.

Volviendo a El Aguador, algunos historiadores se preguntaron, movidos por el extraordinario aspecto de la composición, si no tendría otro significado bajo sus humildes vestiduras. Leo Steinberg fue el primero en sugerir que la escena tenía todas las características de un rito de iniciación, enlazándolo muy acertadamente con relieves clásicos, y que en esa unión del hombre mayor y los jóvenes subyacía el tema de las Tres Edades del Hombre ${ }^{19}$. Julián Gállego sugirió más tarde, que la obra tuviera que ver justamente con ese mismo asunto de la cultura clásica, por la presencia del anciano aguador, de un joven de edad intermedia, que bebe al fondo, y del muchacho que recibe la copa ${ }^{20}$. John Moffitt avanzó en ese camino, pero para él la composición iba más allá; podía ser una alegoría de la Providencia y, basándose en los emblemas utilizados en el siglo XVII, llegaba a considerarlo como uno nuevo, ideado por el artista, sobre la Prudencia y el Buen Consejo ${ }^{21}$. Los intentos de estos tres historiadores del arte resultaron fallidos. En primer lugar, sus explicaciones, aunque bien encaminadas y reveladoras del buen ojo de sus autores fueron poco convincentes, al no ajustarse a lo que en realidad sucedía en la escena velazqueña. La figura del aguador no era la de un anciano ni los dos jóvenes diferían tanto en edad entre sí, como para poder representar apropiadamente las tres edades clásicas del hombre. Por otro lado, sus hipótesis fueron barridas por las explicaciones ortodoxas de un cuadro que no podía ser, según la mayoría, otra cosa que una copia directa y sencilla de la realidad cotidiana de Sevilla. Brown, en su monografía sobre Velázquez, daba por terminadas tajantemente las veleidades interpretativas de sus colegas: «Si el cuadro posee un significado ulterior u oculto, aun está por desvelarse» porque, siempre según el mismo investigador, «El artista llevó el cuadro a Madrid en 1623 (si es que no lo pintó allí) y lo regaló a Juan de Fonseca y Figueroa, cortesano al que había conocido en Sevilla y que le ayudaría a hacerse con una posición en la corte. El Aguador parece así que fue pintado a manera de presentación, lo que explicaría su carácter de catálogo de brillantes efectos» ${ }^{22}$. Jordan, primero, y luego junto a Peter Cherry, en las publicaciones que acompañaron a sus exposiciones, consagraron la obra definitivamente como la pintura de género por excelencia: «This work has traditionally been viwed as a straightforward genre scene related to the world of the picaresque novels of the early seventeenth century. Recently some scholars (e.g. Gállego, Moffitt, Wind) have tended to look for symbolic or emblematic meanings in this, the greatest of Velázquez's youthful works. Part of the painting's potency, of course, is that it resists 'difficult' interpretation. No matter on which level one chooses to

18 Habría que cuestionar si Pacheco, al referirse a los «bodegones» de Velázquez pensaba en las composiciones que en la actualidad se incluyen en ese género o si se refería a puros bodegones o naturalezas muertas, en el sentido habitual del término. La cita en un inventario sevillano de 1655 de tres «bodegones» de Velázquez, (ver T. Kinkead, «Tres bodegones de Velázquez en una colección sevillana del siglo XVII», Archivo Español de Arte, 1979, n. ${ }^{\circ} 52$, p. 185) hace pensar que tal vez el joven artista pintara efectivamente bodegones y mesas de cocina, sin significado alguno y hoy perdidos, pero de los que queda algún eco en malas copias contemporáneas recogidas por W. Jordan en las publicaciones arriba mencionadas, y también otros lienzos diferentes en los que, incluyendo elementos de naturaleza muerta y tratándolos con su naturalismo característico, el verdadero significado de los mismos fuera otro, como sucede en el Cristo en casa de Marta y María.

19 Leo Steinberg, «The Water-Carrier of Velazquez», Art News, 1971, p. 55-56.

20 Julián Gállego, Velázquez y Sevilla, 1974, pp. 131-132.

2) John F. Moffitt, «Image and Meaning in Velázquez's Water-Carrier of Seville», Traza y Baza, 1978, n. 7 , pp. 5-23.

\footnotetext{
22 Jonathan Brown, Velázquez, pintor y cortesano, ed. españolạ, 1986, p. 285, nota 32 y p. 12.
} 
read the picture, in the end its enduring allure is largely visual and derives from the fact that the artist was not very specific, except when it came to what he saw» ${ }^{23}$. En la entrada del catálogo de la última de sus exposiciones sobre naturaleza muerta en la que figuraron los cuadros, Jordan y Cherry describían con rigor el lienzo velazqueño, afirmando «:... the power of the image, then, rests in the probity of the artist's eye and the skill of his brush. And that, more than anything, is the true meaning of this work, which Velázquez took with him to Madrid in 1623 and which became ineradicably identified with his name». En el texto, advertían, sin embargo, la gravedad del personaje cuya dignidad viene comparada con la de un cuadro de asunto religioso ${ }^{24}$, lo que ha sido advertido también por otros historiadores velazqueños al estudiar y describir la obra.

Efectivamente hay algo de religioso en El Aguador y es, desde luego, una obra maestra incuestionable en su análisis de la realidad. Constituye un verdadero tour de force del artista en la representación de la materia y se podría entender más que como un «catálogo de brillantes efectos» (Fig. 4) como un desafío de Velázquez a su fiador, el canónigo don Juan de Fonseca y Figueroa, Sumiller de la cortina del nuevo rey, Felipe IV, y la persona que le abrió definitivamente las puertas de la corte. No hay que olvidar que era Fonseca, como Velázquez, pintor, según afirma Palomino, aunque no pasara de aficionado, y le podemos imaginar extasiado, y tal vez envidioso, ante esos brillantes efectos, imposibles de alcanzar para él, del nuevo cuadro del joven sevillano. En la almoneda de los bienes de su protector, Velázquez adquirió curiosamente su caballete y unas conchas, a modo de pocillos, para mezclar los colores y «un baúl roto y muy biexo», por poco dinero, todo por 76 reales. ¿Necesidad de materiales para su oficio por parte del pintor del rey o afecto por el amigo perdido, pintor mediocre, de quien tal vez quería tener un recuerdo? Velázquez adquirió tambiển unas varas de terciopelo carmesí, en las que gastó más de 700 reales ${ }^{25}$, casi el doble de la cantidad en que había tasado su propio cuadro; él, que ahora sabemos, era nieto de un comerciante de tirantes de terciopelo, al que le suministraba el rico y costoso material su hermano, tejedor de terciopelo en Granada y tío abuelo del pintor ${ }^{26}$.

No parece posible, sin embargo, que buscara Velázquez solamente con esta obra impresionar a Fonseca con su técnica prodigiosa para la captación de la materia; tanto si quería demostrarle lo que era un pintor de verdad como si sólo pretendía sacar con ello provecho y ser presentado al rey. El nuevo Sumiller de la cortina de Felipe IV era un hombre culto, del círculo de humanistas sevillanos en el que se movía también el suegro de Velázquez; «poeta y

23 William Jordan y Peter Cherry, op. cit. 1995 , n. ${ }^{\circ}$ 8. p. 42. (Traducción del texto inglés: «Esta obra ha sido tradicionalmente entendida como una clara escena de género, relacionada con el mundo de la novela picaresca de principios del siglo XVII. Recientemente algunos historiadores (Gállego, Moffitt, Wind) han tendido a buscar significados simbólicos o emblemáticos en esta obra, la más importantes de la juventud de Velázquez. Parte de la potencia del cuadro, desde luego, reside en que se resiste a una interpretación "dificil". No importa el nivel que uno escoja para leer el cuadro, al final su apariencia perdurable es esencialmente visual y deriva del hecho de que el artista no fue muy específico, excepto cuando se refiere a lo que vio)».

${ }_{24}$ W. Jordan y P. Cherry, op. cit. 1995, p. 42 y p. 43, n. ${ }^{\circ}$ 8. (Traducción del texto inglés: «...el poder de la imagen, así, reside en la honradez del ojo del artista y en la maestría de su pincel. Y eso, probablemente más que cualquier otra cosa, es el verdadero significado de esta obra, que Velázquez. llevó consigo a Madrid en 1623 y que ha llegado a identificarse inseparablemente con su nombre».

${ }_{25}$ José López Navío, op. cit. 1961, p. 68.

26 Kevin Ingram «Diego Velázquez's Secret History. The Family Background. The Painter was at Pains to Hide in His Application for Entry into the Military Order of Santiago», Boletin del Museo del Prado, nov. 1999, pp. 76-78. 

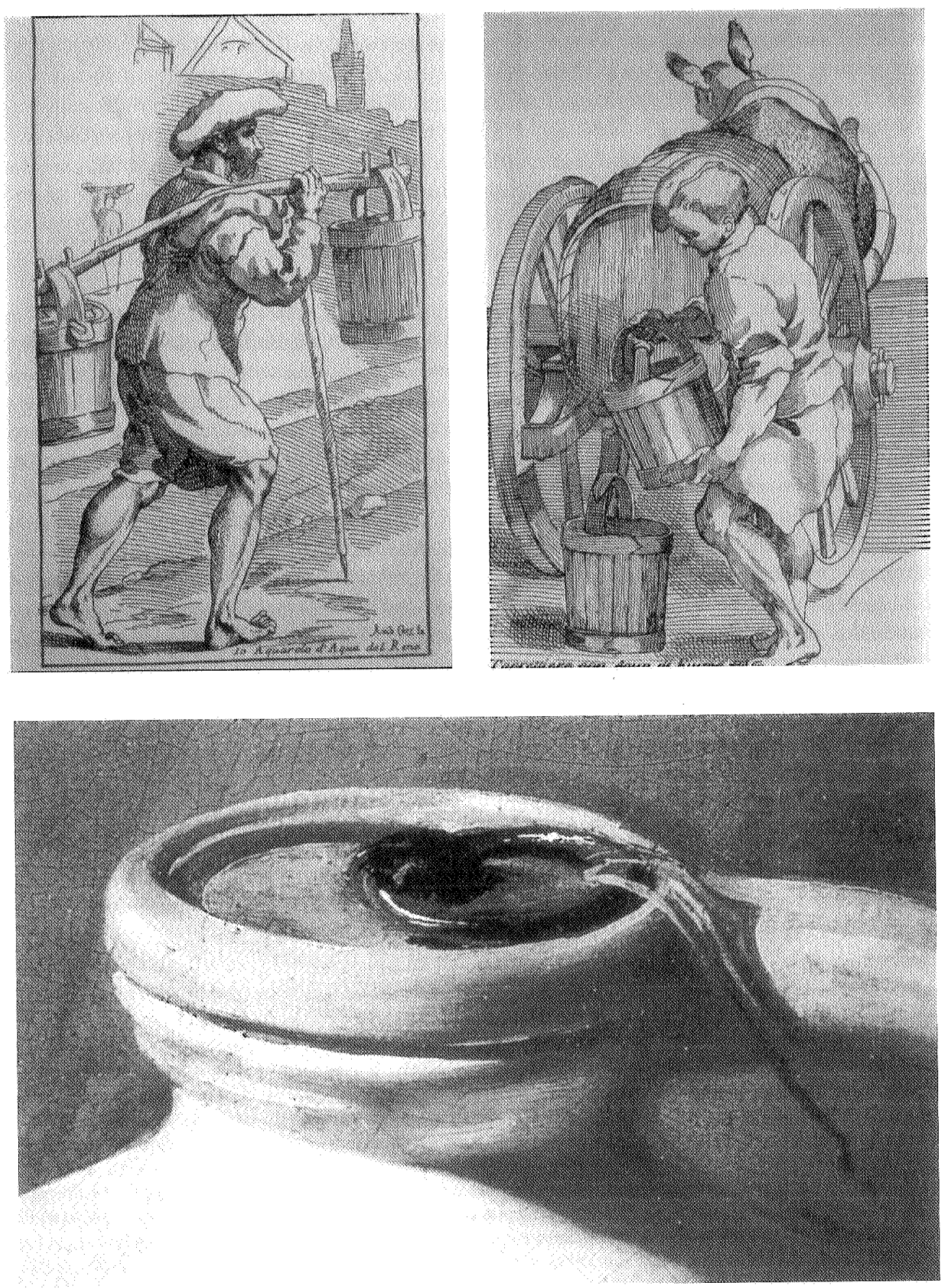

Figuras 2-4. Annibale Carracci: Carretero con agua del río. Arti di Bologna, 1585-1600. (Grabado por Simon Guillain). Annibale Carracci: Aguador de agua del Reno. Arti di Bologna. (Grabado por Simon Guillain). Velázquez: El Aguador, (Detalle). 
docto en lenguas», amigo de literatos ilustres como Lope de Vega ${ }^{27}$, había escrito él también obras que no se llegaron a publicar. El cuadro, por encima de los impresionantes detalles de virtuosismo técnico en la recreación de la realidad, evidencia una profunda y compleja preparación de la escena completa y de lo que en ella sucede. Velázquez, en contra de la opinión de Jordan y Cherry, que no ven en la obra conexión alguna psicológica o emocional entre las figuras, insistió fundamentalmente, a mi modo de ver, en la descripción magistral de las singulares relaciones que se han establecido entre las tres figuras; entre el austero y digno aguador y los jóvenes a los que ha ofrecido su agua y de los cuales, uno, además, el del fondo, quiere hacer partícipe al espectador de lo que sucede en la escena, en un recurso de bien conocida procedencia del arte italiano.

La imagen del hombre maduro está voluntariamente presentada por Velázquez de riguroso perfil, como en un relieve antiguo, ocupando su noble cabeza y su cuerpo erguido el centro exacto de la composición y subrayada su figura, en la parte inferior, por la sólida base que forma el rotundo cántaro del agua. La gran vasija de barro está, además, iluminada con fuerza, muy expresivamente, sugiriendo con ello el pintor que ese cántaro constituye uno de los centros de significado de su escena. En él apoya su mano el hombre, porque de él toma su agua, como de una fuente ritual. A un lado, en el espacio que queda entre la figura del «aguador» y el margen izquierdo del lienzo, casi empujados, pero desde luego subyugados por la presencia poderosa del «aguador», están los dos jóvenes, uno casi un niño. Al otro lado, hacia la derecha, el pintor ha dejado un espacio vacío con el que refuerza la majestad de su figura principal (como más tarde en Las meninas dejaría vacío el amplio espacio de la parte superior, sobre las figuras), sugiriendo además la penumbra silenciosa de un interior. No es la calle con su griterío y movimiento. Los tres están aquí evidentemente šítuados dentro de una estancia y, para definir este hecho con mayor claridad, Velázquez ha colocado una mesa sobre la que descansa la vasija de loza blanca, una alcarraza, tapada con un cuenco lleno también de agua cristalina ${ }^{28}$. Una fuerte iluminación, procedente de una puerta o ventana, hace destacar a figuras y cacharros con la potencia de la luz caravaggesca. Como en otras composiciones tempranas de Velázquez, el juego doble de perspectivas cruzadas, que distorsionan la realidad usando de la geometría, sirve para reforzar los centros de significado sobre los que el pintor quiere llamar la atención del espectador. La mesa, la alcarraza con el cuenco, y el cántaro protagonista están vistos desde una clara perspectiva de arriba abajo, que refuerza su volumen y presencia, acentuados además por el juego de la luz y la sombra de la vasija blanca sobre la mesa. El «aguador», por el contrario, está visto de abajo arriba, con lo que destaca la gravedad de su figura, sólida y elegante como una columna clásica.

El «aguador» se presenta como una figura sagrada, la copa de agua es como el cáliz consagrado, su actitud como la del sacerdote que va a dar la comunión. El niño, como el neófito que recibe un sacramento y el agua que reparte este «aguador» no es el agua de los canales sevillanos ${ }^{29}$, es un agua que comunica en su silenciosa, inmóvil presencia y cristalina materia, una especie de salvación, un modo de vida, una sabiduría antigua. ¿Quizá la de los filó-

27 José López Navío, op, cit., 1961, suministra los datos biográficos más completos de Fonseca, aunque es de esperar que se tengan pronto investigaciones modernas sobre él y el círculo de humanistas sevillanos con quienes estuvo en contacto Velázquez. Sobre la amistad de Fonseca con Olivares y su nombramiento en 1622 como Sumiller de la cortina de Felipe IV, veáse John Elliott, El conde-duque de Olivares, ed. española, 1990, pp. 46, 49 y 156.

28 Para las vasijas en El Aguador, véase Natacha Seseña, «Los barros y lozas que pintó Velázquez», Archivo Español de Arte, 1991, p. 172-179. Todas ellas responden a objetos de uso cotidiano y popular en Sevilla en el tiempo de Velázquez.

29 Carl Justi, op. cit. ed. española, 1999, p. 14. 
sofos griegos, los canes cínicos y estoicos, aquéllos sabios que sólo bebían agua y lo enseñaban a sus discípulos, como forma de vida para alcanzar la verdadera sabiduría? "Se contentan con hierbas, y siempre beben agua fría», decía de ellos Diógenes Laercio ${ }^{30}$ ¿Era posible que el "aguador" fuera la primera representación que hizo Velázquez de uno de esos filósofos antiguos? ¿Antes que su Demócrito? (Fig. 5) ¿Antes incluso que Ribera, que pintó sus primeros ejemplos de filósofos clásicos, vestidos como mendigos y pordioseros contemporáneos hacia 1630 ? $^{31}$. Diógenes Laercio era en la España de principios del siglo XVII bien conocido, única fuente que había llegado desde la Antigüedad para saber algo de los sabios del pasado. Sus Vidas de los filósofos más ilustres, en las que había reunido datos sobre aquéllos varones sabios, pensamientos y anécdotas de sus vidas eran conocidas de poetas y humanistas que leían el griego y el latín de corrido ${ }^{32}$. Las vidas de filósofos antiguos eran ejemplo de virtudes, de austeridad, de sobriedad, de renuncia a los bienes y vanidades del mundo, de autoridad moral ante el poder tiránico, de sabiduría en suma que estaba muy cerca de los ideales más característicos del siglo XVII.

Sí, en el ambiente culto en que el joven Velázquez se había formado, más de uno de esos humanistas amigos de su suegro habría citado y comentado a Laercio. ¿Por qué Velázquez iba a ser menos que otros, que esos pintores italianos, tan valorados por su maestro? ¿Qué impedía que él también pensara sobre la Antigüedad y sus valores morales? Pero eran muchos los filósofos descritos en Laercio y muy pocos hasta entonces los pintores que habían representado a los ilustres varones del mundo antiguo. Si Velázquez había pensado en pintar a uno de ellos, tenía por fuerza que haberse decidido por uno de los más conocidos por su vida, sus historias, sus escritos y sus anécdotas y no por alguno de los oscuros y menos interesantes presocráticos. Más tarde lo haría con Menipo, bien presente en la España del siglo XVII, en la que se traducían y leían los diálogos de Luciano de Samósata, en los que era protagonista absoluto el filósofo y que inspiraron a los más grandes de nuestros escritores y humanistas; o con Esopo, el fabulista universal, citado innumerables veces y considerado también entre los siete sabios antiguos ${ }^{33}$.

El tipo de hombre que presenta Velázquez como «aguador» está aun en su madurez, avanzada, pero no es un anciano. Su rostro está curtido por las inclemencias de una vida al aire libre, pero es fuerte; profundos surcos dibujan sus mejillas, revelando la austeridad de su vida y las privaciones a que se ha sometido. Las arrugas cruzan su frente profunda de pensador, calidad de su personalidad que se manifiesta también en el fruncimiento de sus cejas en

30 Diógenes Laercio describe la conducta y particularidades de los cínicos, muy similares a las de los estoicos, en su vida de Menédemo.

${ }_{31}$ Para Ribera y sus cuadros de filósofos véase Alfonso E. Pérez Sánchez y Nicola Spinosa, Ribera. 1591 1652, catálogo de las exposiciones dedicadas al artista en Nápoles y Madrid en 1991 y 1992, pp. 176, y especialmente la edición inglesa, correspondiente a la exposición celebrada en el Metropolitan Museum de Nueva York, de los mismos autores, 1992, pp. 263-263 y 222-226. También, Oreste Ferrari, «L'Iconografia dei Filosofi antichi nella pittura del Secolo XVII in Italia», Storia dell'Arte, LVII, 1986, pp. 103-181. Sobre las imágenes de filósofos en el siglo XVII véanse también los artículos de Reinhard Brandt en Deutsche Zeitschrift für Philosophie, en 1992, n. ${ }^{\circ} 4$, pp. $133-138$ y 1993, n. ${ }^{\circ} 1$, pp. 54-59 y 339-346. En 1615 se publicaba en Francia un interesante libro que ponía en relación las enseñanzas de los filósofos antiguos, y especialmente de Demócrito, con el mundo cristiano contemporáneo, que tuvo una gran difusión en Roma y Nápoles: Pierre de Besse, Démocrite chrétien, 1615.

32 Numerosas fueron las ediciones de Laercio en Latín; la más cercana al tiempo de Velázquez, la publicada en Lyon en 1585. En italiano, en Florencia, en 1506 y en Venecia en 1611; en francés, en Lyon, en 1612 (véase nota 49).

33 Francisco Rico, «Los filósofos de Velázquez o el Gran Teatro del Mundo», El Paseante, 1991, n. ${ }^{\circ}$ 18/19, pp. $50-62$. 
un gesto característico de reflexión o en su mirada severa y melancólica (Fig. 6), que dirige hacia el cuenco lleno de agua, como perdido en una profunda meditación. Velázquez está evidentemente creando una imagen compleja, no copiando un modelo cualquiera del natural. Como los artistas del Renacimiento en la construcción de sus ejemplos de belleza ideal, Velázquez ha reunido aquí, sin duda, los caracteres y rasgos de varios modelos, es posible que algunos tomados de figuras reales, de mendigos y vendedores ambulantes, pero utilizando también con absoluta certeza modelos de la estatuaria clásica, de los retratos romanos, especialmente de los del período republicano (Fig. 7) ${ }^{34}$. El tipo humano que resulta de ello es el de un hombre severo, acostumbrado a mandar con autoridad, austero, profundamente reflexivo y sabio, pues la acción que está llevando a cabo, aunque sencilla, es en él resultado de una profunda meditación personal sobre la vida y las cosas. El pelo, muy corto, presenta unos curiosos trasquilones, como si estuviera rapado desigualmente con una navaja, pocas veces señalados en la literatura sobre el lienzo, y viste un amplio capote ${ }^{35}$, que también llama la atención en la apariencia toda de esta figura. Es de amplias mangas abiertas que dejan ver una camisa de lino blanquísimo (Fig. 8); es también pesado, de lana basta, abierto por delante, que le envuelve por completo, pero no está roto, sino cuidado, lo que evidencia la huella de sus dobleces. Es su única pertenencia, como el palio o manto de los filósofos antiguos, eso y el cántaro, porque la vasija de loza fina y sobre todo la copa de vidrio de Venecia ${ }^{36}$ pertenecen a los otros, al niño, a la casa, evidentemente.

La imagen de pedagogos de casi todos los grandes filósofos que describía Laercio tendría que quedar algo empañada en el siglo XVII, incluso para los humanistas, por la amorosa inclinación que todos aquellos sintieron hacia sus jóvenes discípulos, en un siglo en que en España se condenaba a muerte a los que incurrían en el «pecado nefando». Sólo uno de aquéllos ilustres varones antiguos no había caído en la tentación de los jóvenes éfebos, Diógenes ${ }^{37}$. El filósofo de Atenas, nacido en Sínope, según cuenta Laercio fue un compendio de las virtudes y del modo de ser de los filósofos antiguos. De vida frugal y parca «loaba mucho», según Laercio, "a los que pueden casarse y no se casan, a los que les importa navegar y no navegan, a los que pueden abusar de los muchachos y se abstienen de ello; a los que tienen oportunidad y disposición para vivir con los poderosos y no se acercan a ellos» ${ }^{38}$.

${ }^{34}$ El estudio de la estatuaria antigua, romana, que pudo ver Velázquez en colecciones sevillanas está aun por hacer. He ilustrado por ello un conocido retrato romano de época republicana, el de Villa Torlonia, cuyas facciones severas, de rasgos marcados y profundos surcos, ilustran muy bien el tipo humano que describe Velázquez en su «aguador». Igual valdría otro retrato (fig. 17), conservado en el Museo Municipal de Jerez de la Frontera.

${ }^{35}$ Información facilitada por doña Carmen Bernis, que me señala asimismo el libro de sastrería de Rocha Burguen, Geometría y traça perteneciente al oficio de Sastre, Valencia, 1618, con patrones de capotes similares. Éste sería «capote de paño para serrano o ganadero»; es decir, prenda popular y no para señores.

${ }_{36}$ Elena Ramírez-Montesinos, «Objetos de vidrio en los bodegones de Velázquez», V Jornadas de Arte, Departamento de Historia del Arte, Centro de Estudios Históricos, C.S.I.C., Madrid, 1991, p. 403. La autora del artículo rebate la tesis de que la forma oscura que aparece en el interior del vaso sea de un higo, fruta utilizada, al parecer, en Sevilla para dar sabor al agua. Según ella, se trata de la decoración interior característica de ciertas valiosas copas de vidrio soplado veneciano, que se hicieron también en España en Cadalso de los Vidrios. Tanto si se trata de este tipo de copas, como si es otra de carácter más sencillo, pero con un higo en el agua, lo esencial aquí es la utilización por Velázquez, para ese detalle importante en el significado de su cuadro, de una exquisita y frágil copa de vidrio fino, de gran valor, que revela la riqueza o abundancia en que vivía su propietario (ver también nota 45).

37 En marcha esta investigación, así como mi propuesta de El Aguador como una representación del filósofo griego Diógenes, Anna Reuter, becaria en el Museo del Prado, me señaló la curiosa publicación de Anton Heber, Diego Velázquez. Porträt der Humanität, 1994, pp. 92-95, en la que su autor apunta la idea de que el cuadro ilustre al filósofo Tales de Mileto y su teoría sobre el agua como principio de todas las cosas. De nuevo, la falta de correspondencias precisas entre la vida de Tales y la escena de Velázquez invalidan, a mi juicio, esa hipótesis.

${ }^{38}$ Cito a Laercio por la edición de José Ortiz y Sanz, del siglo XVIII la primera publicada en España. No se recoge en cada cita el número del apartado correspondiente en la vida del filósofo, por entender que su vida entera es de interés para la comprensión de la tesis de este artículo. 

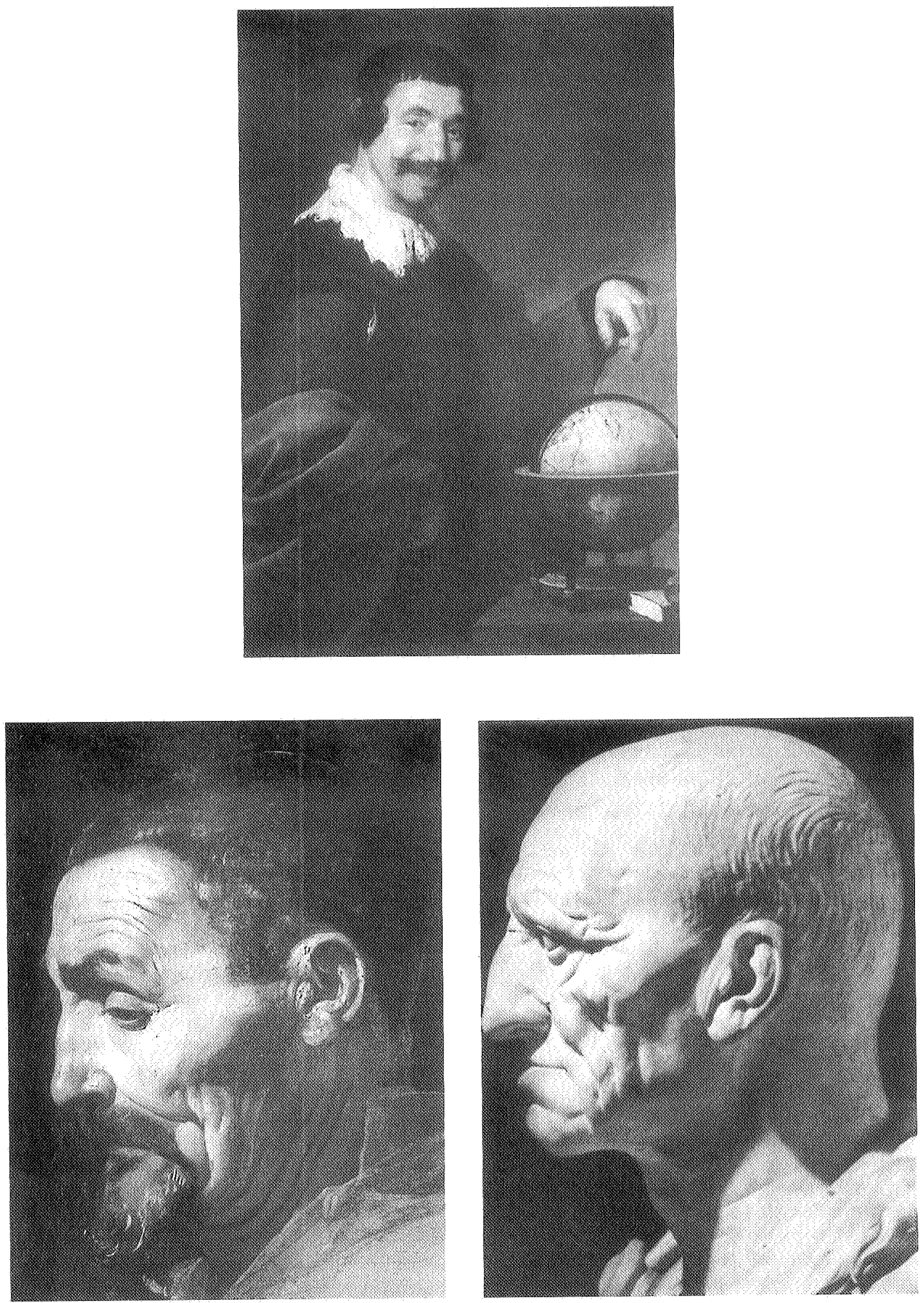

Figuras 5-7. Velázquez: Demócrito. Rouen, Musée des Beaux-Arts. Velázquez: El Aguador (Detalle). Busto de patricio, época republicana. Roma. Museo de Villa Torlonia. 
Según algunos fue el primero de los filósofos que utilizó su palio, o manto, doblado para dormir y Laercio cuenta que «caminaba a pie descalzo sobre la nieve» y que "por el estío se echaba y revolvía sobre la arena caliente, y en el invierno abrazaba las estatuas cubiertas de nieve, acostumbrándose de todos modos al sufrimiento». Fue también, en eso como el resto de sus compañeros, fustigador de las vanidades y riquezas y Laercio pone en su boca sentencias que demuestran su austeridad: «Solía decir que habían caído sobre él las imprecaciones de las tragedias, pues ni tenía ciudad ni casa, estaba privado de la patria, era pobre, errante y pasaba una vida efímera. Que oponía a la fortuna el ardimiento; a la ley la naturaleza, y la razón a las pasiones» y «tenía por cosa pueril la nobleza, la gloria mundana y demás cosas así, diciendo son adornos de la malicia». Habitaba en una cuba de madera y despreciaba las cosas superfluas, utilizaba su palio para dormir y en su zurrón llevaba todo lo que poseía: «Habiendo visto una vez que un muchacho bebía con las manos, sacó su colodra del zurrón y la arrojó diciendo: 'Un muchacho me gana en simplicidad y economía'. Arrojó también el plato, habiendo igualmente visto que otro muchacho, cuyo plato se había quebrado, puso las lentejas que comía en una poza de pan». Tema éste que fue representado en el arte, y precisamente en el siglo XVII por un contemporáneo de Velázquez, el francés Nicolas Poussin ${ }^{39}$. Fue, quizá, Diógenes el más radical de sus compañeros filósofos en sus críticas al poder y en el zaherir con sus actitudes y palabras la soberbia de los poderosos: «Preguntado una vez por un tirano qué metal sería mejor para una estatua, respondió: 'Aquél de que se fundieron las de Harmodio y Aristogitón'», los famosos tiranicidas. El pasaje más conocido de su vida, también representado en el arte del siglo XVII, es quizá el que se refiere a Alejandro, cuando «Estando cogiendo el sol en el Cranión se le acercó Alejandro y le dijo 'pídeme lo que quieras', a lo que respondió él: 'pues no me hagas 今̈̈̈mbra». Su actitud ante los poderosos no era más que reflejo de su libertad como hombre, que se evidencia en numerosas ocasiones en las páginas de Laercio dedicadas al filósofo: «Entraba en el teatro contra la gente que salía, y preguntado por qué, respondió: 'Esto tengo resuelto hacer toda mi vida» y «Preguntado que es lo mejor en los hombres, respondió 'La libertad en el decir'» y afirmaba que «su vida se conformaba con la de Hércules, que nada prefería a su libertad». Son todas máximas y modelos de vida y de sabiduría que aparecen también en otros filósofos de la antigüedad y en los textos clásicos. Modelos de vida que conformaban, además, los ideales del siglo XVII, en otros países también, pero en España muy especialmente.

Una de las anécdotas, recogidas por Laercio, sobre el carácter independiente y por encima de las convenciones sociales de Diógenes es, sin embargo, de interés específico para el lienzo de Velázquez: «Habiendo entrado una vez al convite de ciertos jóvenes con la cabeza a medio esquilar le dieron algunos golpes: pero él escribiendo después los nombres de los que le habían dado en una tablita blanca, se la ató encima y anduvo con ella. De este modo vindicó su injuria, exponiéndolos a la reprensión y censura de todos». Velázquez debió de estudiar con atención los escritos de Laercio, para encontrar en ellos detalles que le ayudasen a conseguir la dificilísima caracterización de su personaje, pues el extraño corte de pelo del "aguador", a trasquilones en zigzag, responde, como es lógico, a un deseo voluntario de Velázquez de representarlo así y no de otro modo. Es importante observar que en las dos repre-

${ }^{39}$ Para la iconografía de Diógenes en el siglo XVII, así como algunos ejemplos del XVI y anteriores, véase A. Pigler, Barockthemen, 1956, vol. II, pp. 370-375. Es frecuente la representación del filosofo arrojando su cuenco para beber con la mano, así como sentado en su tonel ante Alejandro; también su búsqueda de un hombre por las calles de Atenas, utilizando una linterna, y su definición del hombre de Platón. 
sentaciones que Ribera hizo de Diógenes, años después, una fechada en 1628 o 1630 y la otra ya de mediados del decenio de 1630, el filósofo lleva también el pelo revuelto, cortado a trasquilones ${ }^{40}$ (Figs. 9 y 10). Como más tarde haría en la creación de su Menipo y del Esopo, para los que no tenía precedentes, o de su Demócrito, en el que quizá voluntariamente abandonó los precedentes conocidos, entre otros el de Rubens en España ${ }^{41}$, Velázquez buscaría con detenimiento, quizá ayudado por sus amigos cultos, aquéllos pasajes de la vida y personalidad del filósofo más susceptibles de interpretación visual. Entre ellos, el pelo muy corto; su limpieza, que menciona Laercio: «Nuestro filósofo iba siempre muy limpio, a causa de que se ungía»; y sus vestiduras, pues refiriendose a Crates, discípulo de Diógenes, Laercio recogía un epigrama del autor satírico Filemón: «En verano llevaba ropa burda, y delgada en invierno, para tomar lecciones de templanza», lo que se puede aplicar aquí a Diógenes, vestido con grueso capote en el calor del verano en que es necesaria el agua fresca. No abandonaría, sin embargo, otros detalles, más sutiles y difíciles de representar, como la dureza de su vida, la personalidad del filósofo, del que emanaba autoridad, y su carácter reflexivo. Imaginaría luego, en su cabeza de artista genial, el aspecto externo de aquél hombre, para trasladarlo al lienzo. En ese proceso se ayudaría seguramente de modelos vivos, conocidos unos, sirva de ejemplo el aldeanillo famoso del que hablaba Pacheco, dibujado innumerables veces hasta dominar sus expresiones; entrevistos otros en la calle y memorizadas sus facciones interesantes por su portentosa retentiva de pintor. Pero utilizó modelos de la escultura clásica, retratos romanos, ya mencionados, que, cómo ningún otro ejemplo posterior, habían dominado juntamente las facciones y las virtudes de sus modelos. Consiguió en el lienzo finalmente la apariencia externa, la traza de Diógenes, pero con ella también la captación de la personalidad más profunda de aquél y de sus valores morales, lo que constituyen aquí, por encima de todo lo demás, el prodigio expresivo de este lienzo.

Velázquez supo acertar en la caracterización perfecta de un hombre libre, reflexivo, austero, con dominio de sus pasiones, por encima de las convenciones sociales y con autoridad moral para mandar sobre sus semejantes, de lo que se preciaba Diógenes. En una de las ocasiones en que fue vendido como esclavo «preguntándole el pregonero 'qué sabía hacer' respondió 'Mandar a los hombres' y señalando con el dedo a cierto corintio que pasaba por allí muy bien vestido, dijo: 'Véndeme a éste; éste necesita de amo'. Comprolo en efecto Xeníades, llevóselo a Corinto; lo hizo preceptor de sus hijos y administrador de toda su casa. Portóse en ella de manera que Xeníades decía por todas partes: 'El buen genio vino a mi casa'». Pero no para en esta cita la relación de Diógenes con Xeníades que narra Laercio. No serviría un solo pasaje del texto, o las consabidas máximas sobre la conducta en la vida, para pensar que se tratara aquí efectivamente de ese filósofo y no de otro. Diógenes, sin embargo, aparece citado en varias ocasiones específicamente, quizá como ningún otro de sus compañeros, como maestro de jóvenes, a través de sus sentencias y admoniciones o a través de su magisterio concreto: "Tenía una persuasiva maravillosa, tanto que a cualquiera embelesaba fácilmente con sus palabras. Por tanto se refiere que un tal Onesicrito, egineta, envió a Atenas a uno de sus dos hijos, llamado Andróstenes, el cual, luego que oyó a Diógenes, se quedó

40 Ribera utilizó un tipo humano que revela ciertas concomitancias con el de Velázquez, pero parece que ninguno de los dos artistas conocieron la escultura clásica que con bastante seguridad representa a Diógenes, Gisela M.A. Richter, The Portraits of the Greeks, Londres 196.5, pp. 181-185. Debo esta información al Dr. Stephan Schröder, que me proporcionó bibliografía sobre la materia y quien me apuntó asimismo la idea de que es posible que en el siglo XVII se le dieran a Diógenes los rasgos de algún otro de los retratos considerados entonces de filósofos antiguos, investigación que no he llevado a cabo.

41 Francisco Rico, op. cit. 1991, p. 53. El Demócrito y Heráclito de Rubens, adquirido por el Estado español, pasará al Museo de Escultura de Valladolid. 

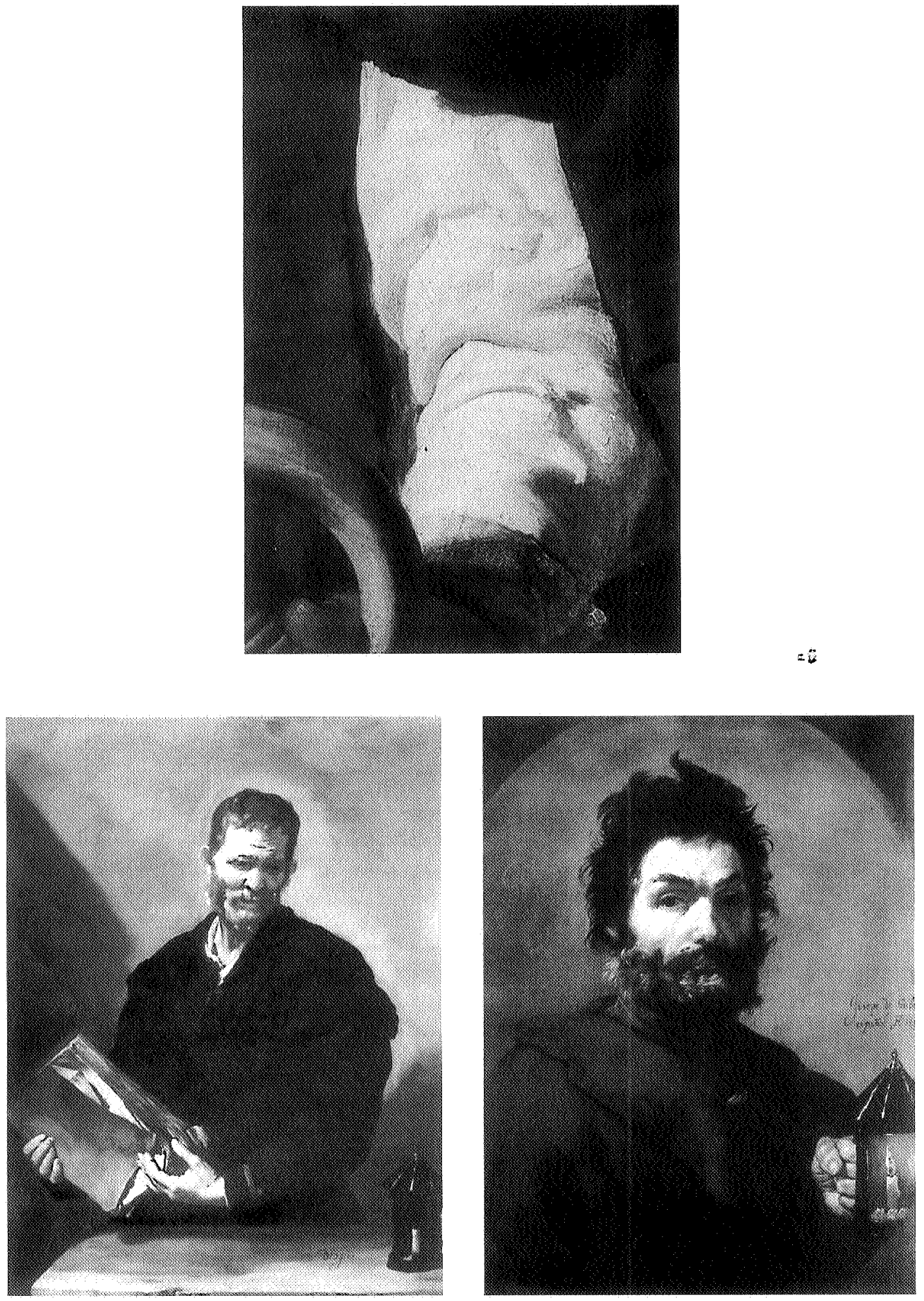

Figuras 8-10. Velázquez: El Aguador (Detalle). José de Ribera: Diógenes, 1636. Colección privada y Diógenes. Dresde. Staatliche Kunstsamunlungen, Gemäldegalerie Alte Meister. 
allí; envió después al otro hermano, que era mayor, llamado Felisco, de quien ya hicimos memoria, y se quedó también; y finalmente fue alli el mismo Onesicrito, y no menos se quedó con sus hijos a estudiar la Filosofía. Tanto hechizo contenía la escuela de Diógenes». Esa cualidad de su labor de magisterio, que se desprende de la lectura completa de la vida de Diógenes que hace Laercio, se hace de repente sugestiva y reveladora en lo que concierne al «aguador» velazqueño, cuando se llega al pasaje de la relación del filósofo con su amo, Xeníades, ya apuntada más arriba, que conviene citar in extenso:

«También Eubulo en el libro igualmente intitulado La Almoneda de Diógenes, dice que instruyó a los hijos de Xeníades, de manera que después de haberles enseñado las Disciplinas, los adiestró en el montar a caballo, a disparar la flecha, tirar con honda, y arrojar dardos. Después no permitía que el que instruía a los muchachos en la palestra ejercitase los suyos para ser atletas, sino sólo para adquirir buen color y sanidad. Sabían de memoria estos muchachos varias sentencias de los poetas, de otros escritores, y aun de Diógenes mismo; y para que mejor aprendiesen les enseñaba todas las cosas en compendio. Enseñábales también a servir en casa, a comer poco y a beber agua. Hacíales raer la cabeza a navaja; los llevaba por las calles sin adornos, sin túnica, descalzos, con silencio y sólo mirándolo a él. Llevábalos también a caza. Los discípulos tenían igual cuidado con él, y lo recomendaban a sus padres encarecidamente. Refiere el mismo autor que envejeció y murió en casa de Xeníades, y lo enterraron sus hijos...».

El lienzo de Velázquez tiene los suficientes puntos en común con esta descripción de Diógenes como pedagogo y preceptor de los hijos de Xeníades, como para no pensar que el pintor quisiera aquí, efectivamente, representar al gran filósofo de la Antigüedad y precisamente en su labor de magisterio y no otra. Se explica ahora el cántaro monumental ${ }^{42}$, en primer término, que contiene el agua, símbolo aquí empleado por Velázquez para expresar visualmente la sabiduría del filósofo y sus máximas de conducta moral, de su austeridad, de su vida natural y sencilla ${ }^{43}$. También Laercio recoge en la vida del estoico Zenón una descripción hecha por el mismo autor satírico Filemón en su obra Los Filósofos: «Pan e higos secos comel y agua bebe; una Filosofía nueva enseña;/ Enseña a tener hambre y para ello discípulos recoge». La otra vasija sobre la mesa, en la que descansa el cuenco lleno de agua (Fig. 11), recibe la mirada pensativa de Diógenes, tal vez alusión velazqueña al hecho de que rechazara beber de un cuenco pudiendo beber con sus manos. El artista describe la superficie de la tinaja y la ilumina con luz potente, lateral, para que resalten las gotas de agua que resbalan por su panza, señal de que está llena, rebosante de esa agua de sabiduría, que rezuma por la materia porosa del barro (Fig. 12). En otro de los pasajes de Laercio afirma que Diógenes «era amado de los atenienses; pues a un mozo que le quebró la tinaja lo castigaron con azotes, y a Diógenes le dieron otra». Una vez más, Velázquez ha buscado elementos reales de la vida del sabio que le ayudaran a caracterizar a su hombre. El filósofo apoya aquí su mano izquierda sobre ese cántaro, que es suyo, y con la derecha sirve la copa de cristal a uno de sus discípulos, el más joven. El gesto, de impecable dibujo ${ }^{44}$ (Fig. 13), es

${ }^{42}$ El cántaro presentado por Velázquez responde al tipo de vasija de esas características de las fabricadas por ejemplo en Lucena o en Málaga. Véase Natacha Seseña, op. cit. 1991, p. 175.

${ }_{43}$ El agua aparece en numerosas ocasiones como la bebida de los filósofos cínicos y estoicos. En Laercio, aparte de las mencionadas en el texto, son innumerables las citas que hacen referencia a la abstención de cualquier otra bebida que no fuera el agua, convirtiéndose en un símbolo, además, de conducta moral.

44 No existe entre la documentación del cuadro, que se guarda en la National Gallery de Londres, radiografía del mismo, por lo que es difícil saber si hubo cambios y arrepentimientos en la composición, pues éstos no se aprecian en la superficie de este lienzo, salvo algunos retoques en el perfil del manto del «aguador». La belleza y perfección del dibujo de las manos del «aguador» y del muchacho que sostiene la copa indican que Velázquez concibió y preparó su composición con gran cuidado, haciendo seguramente dibujos de los detalles más complicados 

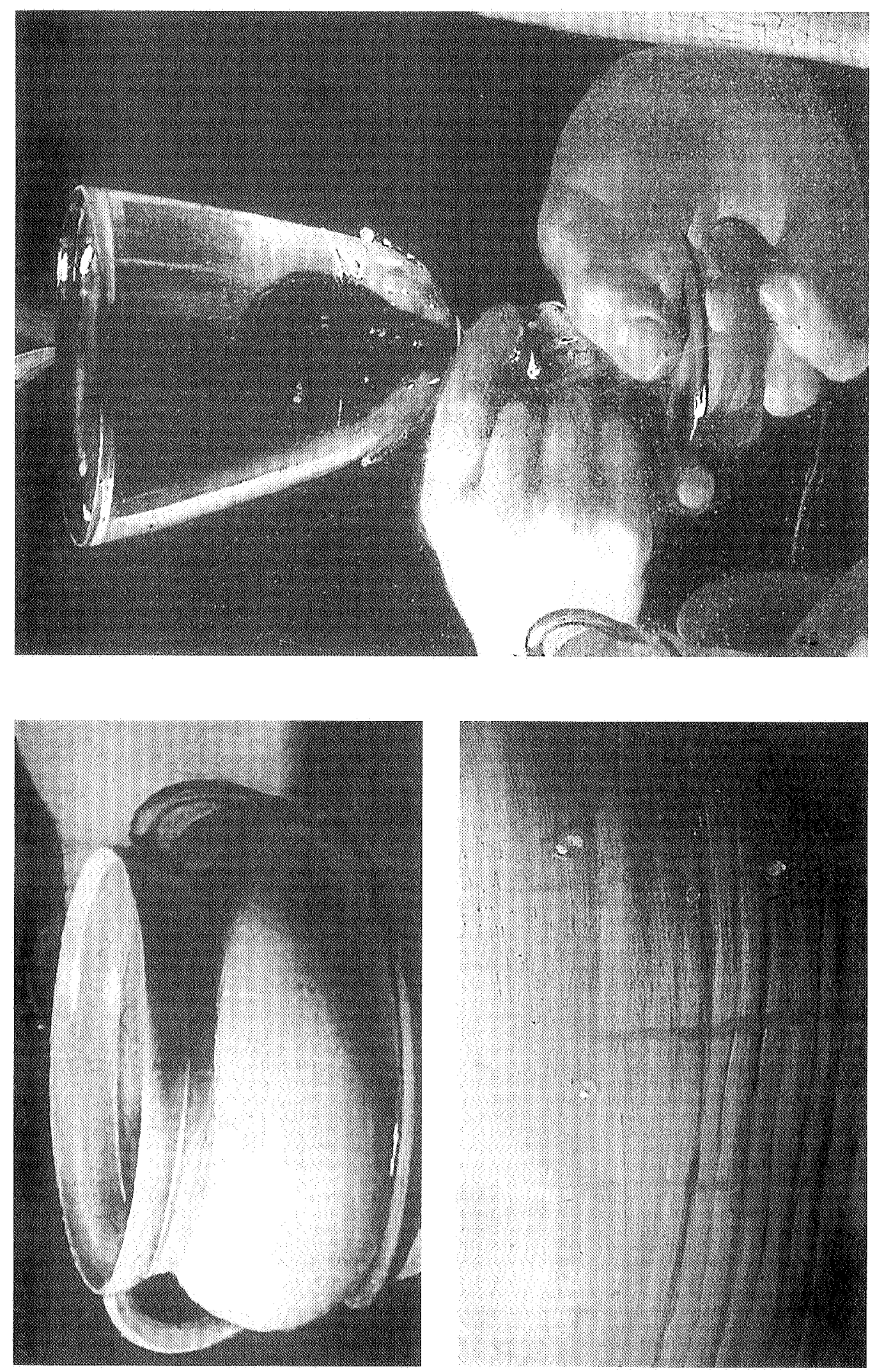

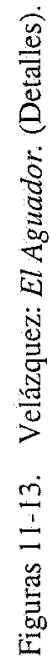


pensado, lento, cargado de intención, similar al del rey mago Baltasar que en la cercana en el tiempo Adoración de los reyes del mismo Velázquez, entrega al Niño la copa sagrada llena allí de mirra. El muchacho mira a su maestro, a su modelo, fija y directamente al cuerpo, siguiendo fielmente su magisterio, «con silencio y sólo mirándolo a él» (Fig. 14). La copa, de fino cristal veneciano ${ }^{45}$, trasparente y pura, llena de agua hasta los bordes, es de nuevo el modo, único y personal, con el que Velázquez representa en su muda pintura la riqueza de la casa noble del niño, vestido además con jubón de paño o terciopelo oscuro y fina camisa de holanda con cuello de dos trenzas, no a la manera de los pícaros de las novelas contemporáneas. Con la frágil copa de vidrio, Velázquez ha querido también, sin duda, expresar con una acertada imagen visual, (haría algo semejante en la jarra de barro de su Menipo, y no es necesario insistir en tantas referencias literarias a la fragilidad de ese material), esa misma fragilidad de la vida, así como la vanidad y fugacidad de las riquezas y de la nobleza que señalaba Diógenes.

El otro muchacho, algo mayor que su hermano, menos maleable por tanto para el aprendizaje, aparece al fondo, bebiendo de una vasija distinta, de loza vidriada ${ }^{46}$. Es la figura, como decía más arriba, que Velázquez ha utilizado en su pensada composición para introducir al espectador en la escena y en lo que en ella sucede; es quien transmite, desde la sombra, su mensaje verdadero, quien (la pintura es muda) nos cuenta, a través de su expresión, que las enseñanzas del filosofo no son fáciles, que el camino de la sabiduría y de la virtud es áspero (Fig. 15). Apura la bebida y su mirada se fija intensa, atribulada y dudosa, en nosotros. Si es agua lo que bebe, le resulta difícil renunciar a otras bebidas más gratas; si es vino, es su último vaso; a partir de ese momento comienza el camino de perfección, su renuncia a los placeres. Diógenes decía también que «la ejercitación es de dos maneras; una del alma y otra del cuerpo... Aun el mismo desprecio del deleite puede sernos gustosísimo una vez acostumbrados, pues así como los acostumbrados a vivir voluptuosamente con dificultad pasan a lo contrario, así también los ejercitados contra los deleites fácilmente los desprecian».

Es evidentemente una escena de iniciación, como apuntaba ya Steinberg con fina agudeza de profesor universitario, pero no genérica, una cualquiera, sino concreta; esa y no otra, basada en un texto clásico específico, bien conocido en el ambiente español culto de la Sevilla de principios del siglo XVII en que se formó Velázquez. Todo en la composición está perfectamente calculado, apoyándose además para ello el pintor en su prodigiosa técnica, que le permitía explicar, sin palabras, la acción, que no es aquí «difícil» sino sencilla y directa, aunque se sirva Velázquez de un conjunto de elementos en cuya conjugación tuvo que hacer uso de una necesaria complejidad. Desde la posición en que quería cada figura, hasta la

y tal vez de la escena completa. Hay que descartar la idea de que fue una copia del natural o incluso de que la preparase en el taller, con los cacharros y los modelos ante él, para copiarlos directamente en el lienzo, ya que no era ese el sistema de trabajo y de preparación de los cuadros de ese tiempo en España; no aparece tampoco descrito este modo de trabajar, por ejemplo, en el Arte de la Pintura de Pacheco, que sí se refería, sin embargo, a la utilización de estampas, de dibujos y de bocetos al óleo entre los pintores españoles para organizar sus composiciones. La presentación de perfil del personaje principal sugiere que Velázquez hubiera podido inspirarse, también aquí como para el rostro, en algún relieve o medalla clásica.

45 En la nota 32 se habla del tipo de copa de vidrio que pudo presentar aquí Velázquez y se acepta en este estudio que pueda ser de las que llevaban en su interior una decoración especial de vidrio soplado de otro color. Sin embargo, en apoyo de quienes vieron en ella un higo, para dar perfume al agua, conviene señalar que en la vida de Diógenes, así como en la de otros filósofos antiguos, una de las comidas más frecuentes y preciadas eran precisamente los higos. Diógenes los pone incluso como ejemplo de su filosofía: «Habiéndole Hegesias pedido alguno de sus escritos para leerlos, le dijo: 'Necio eres, Hegesias, que buscas los higos pintados, y no los verdaderos, dejando la verdadera y efectiva ejercitación y yéndote a la escrita».

46 Véase Natacha Seseña, op. cit .1991, p. 175. 

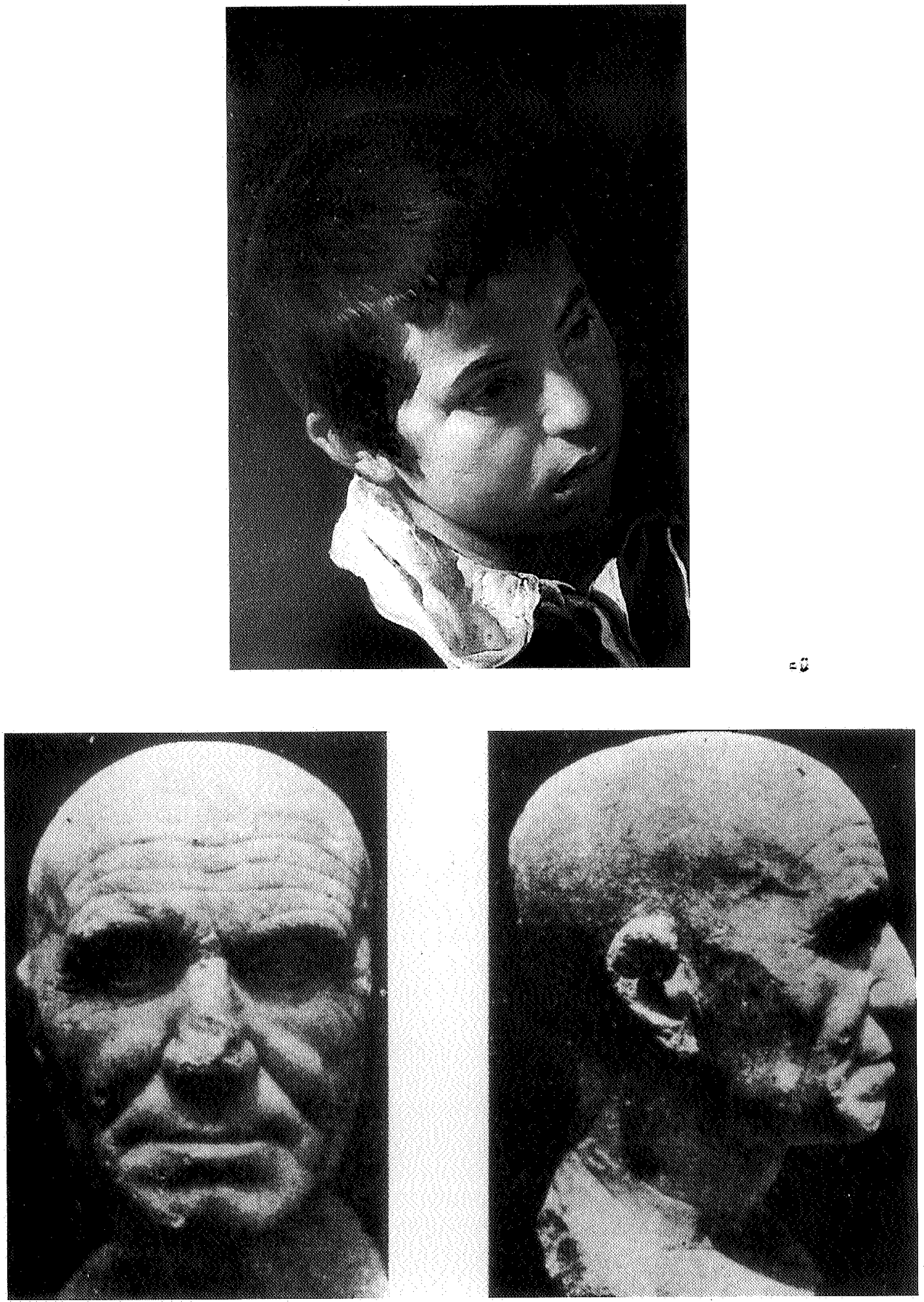

Figuras 14 y 15. Velázquez: El Aguador (Detalle). Busto romano. Época republicana. Jerez de la Frontera. Museo. 
materia y forma de las vasijas y recipientes; desde el lugar en que sucede la acción, hasta su iluminación, que insiste en el agua y en el sabio varón, iluminado él y su «mercancía» por la luz de la sabiduría, mientras que aun están en la penumbra, de la ignorancia, sus jóvenes discípulos. Como en su Menipo y Esopo, el pintor ha creado, como era su obligación de artista, una nueva realidad, con la que pretendió explicarnos la vida y el pensamiento de su protagonista, Diógenes, bajo las vestiduras de sus contemporáneos. Porque también en la elección del capote, para vestir al filósofo hay intención del artista y no pura casualidad de la realidad de su entorno. El capote, por su corte y apariencia era quizá la prenda más cercana al antiguo palio de los filósofos estoicos: cuadrado y corto, abierto por delante. El pintor rebuscaría entre sus conocimientos del mundo antiguo para vestir a su «aguador» de modo que resonara en sus amigos cultos la idea de la vieja prenda, intemporal, del mundo mediterréno. Utilizando el capote, de mangas abiertas, había vestido también Ribera a su Demócrito (Figs. 16 y 17), de fecha temprana, pues todos están conformes en fecharlo hacia 1615 o 1617, ligeramente anterior a El Aguador.

El Aguador de Velázquez es una obra magistral, pero no sólo, por tanto, por la belleza de los pasajes de naturaleza muerta que hay en ella, sino por la profundidad con que el joven pintor planteó su moderna meditación sobre las enseñanzas de la Antigüedad. Se entiende ahora la afirmación del culto e ilustrado Ponz cuando afirmaba con su sensibilidad de conocedor que Velázquez «ejercitó filosóficamente la pintura». No porque tratara aquí un tema filosófico sino por el modo riguroso, sabio y reflexivo con que el artista quiso transmitirnos su pensamiento. No es comprensible que un hombre de inteligencia superior, un genio, como fue Velázquez, pintara sin un planteamiento previo, sin contarnos una historia, sin resolver magistralmente las relaciones de los personajes de sus cuadros, como hicieron sus contemporáneos literatos. ¿Es El Quijote acaso un cúmulo de anécdotas pintorescas, tratadas con realismo, como se decía de El Aguador? ¿Por qué la Pintura, que en aquél tiempo venía comparada con la Poesía, Ut Pictura Poesis, no se ve en nuestros días como un ejercicio de suprema inteligencia y de coherencia intelectual? ¿Qué hemos perdido, en el mundo de las rápidas imágenes televisivas, para no entender la expresiva carga de una obra como ésta, en la que instintivamente presentimos su mensaje?

¿Iba destinado El Aguador a Juan de Fonseca y Figueroa, su primer propietario? Es muy probable que así fuera, pero no sólo por las razones que se han dado hasta ahora, es decir como regalo del pintor a su protector, traído bajo el brazo en su viaje a Madrid icomo traían antes en España los pollos vivos a la casa de la ciudad a la que habían sido invitados los del pueblo! En la corte, el canónigo Fonseca, era Sumiller de la cortina del rey Felipe IV y sería su embajador extraordinario en Parma, pero en Sevilla, en donde residió hasta su llamada a la corte por el conde-duque de Olivares, Fonseca era nada menos que canónigo maestresçuela de la catedral, habiendo sido nombrado para ese puesto en 1607. Todavía en 1627, en su testamento se definía como tal: "Sepan Quantos esta carta de testamento (lean) la final y postrera voluntad q. Otorgo yo $D$. Ju $u^{a}$. Fonseca y Figueroa, sumiller de la cortina de S. Mgd. y canónigo maestrescuela de la Sta. Yglesia de Sevilla...» ${ }^{47}$. Según Covarrubias en su Tesoro de la Lengua Castellana, de 1611, mestrescuela «unas veces se toma por el que enseña a los niños a leer y escribir, otras por la dignidad que tiene ese nombre en las iglesias catedrales y preeminencia en la universidad o estudio: Latine gymnasiarcha et praefectus scholae. Está en su cuenta en el coro enmendar la escritura de los libros y los malos acentos y en el estudio presidir y dar los grados que sin otras cosas particulares conforme a los estatutos y

47 José López Navío, op. cit. 1961, p. 68. 


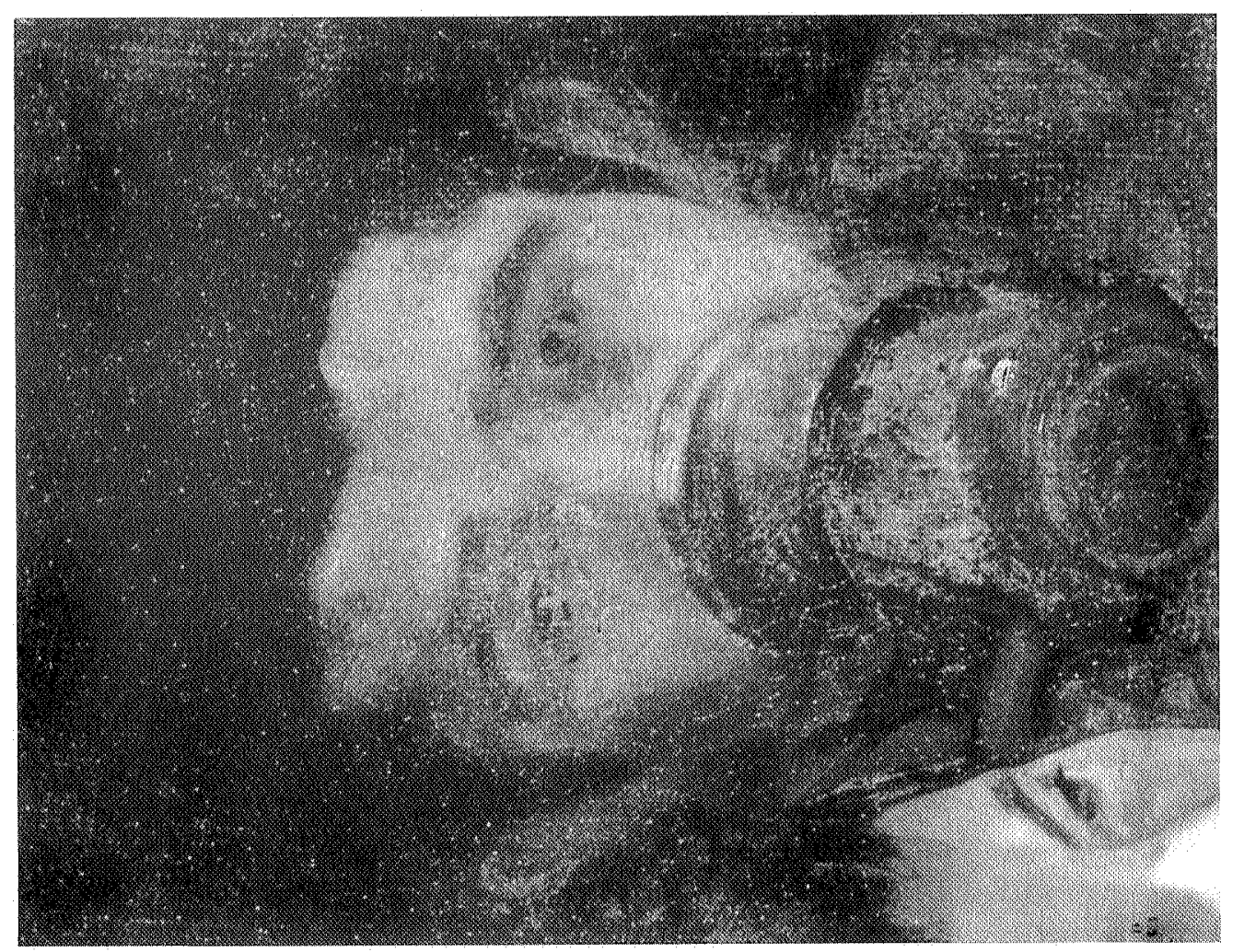

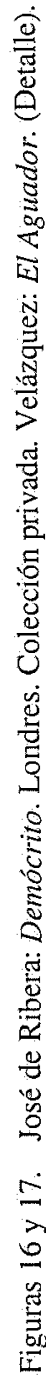


costumbres de las iglesias y universidades». Es posible que Velázquez pintara su cuadro como regalo para Fonseca, al que, además, al llegar a Madrid, obsequió con un retrato de su mano, según cuenta Pacheco ${ }^{48}$, pero parece más lógico que lo hiciera cuando el canónigo vivía aun en Sevilla, como maestrescuela de la catedral, a modo de «retrato moral» del propio Fonseca, quizá un neoestoico, corriente filosófica seguida por tantos humanistas españoles de ese tiempo. En ese caso, habría que revisar la fecha y no situar El Aguador en 1623, sino antes, quizá entre 1619 y 1621, junto a otras obras de esos años con las que su relación es evidente por técnica y colorido. Habría que plantearse, quizá, si fue un regalo de Velázquez, atento siempre a sus intereses y previendo su futuro, o un encargo de los cultos amigos del canónigo, ante el anuncio de su marcha a Madrid, llamado por el conde-duque, y a donde llegaría en abril de 1622. Aunque no habría que descartar que se lo pidiera a Velázquez el propio Fonseca, que conocía bien a los clásicos ${ }^{49}$. Repasando el inventario de sus bienes, es importante mencionar que el canónigo tenía una importante biblioteca, que adquirió a su muerte con las librerías, estantes y otros cajones, así como los emperadores romanos de mármol y medallas, el cardenalinfante ${ }^{50}$, que también adquirió de Bracamonte, como vimos más arriba, el lienzo de El Aguador. Es bien sabido que imágenes de filósofos de la Antigüiedad decoraban las bibliotecas y analizando el inventario de los bienes de Fonseca, junto con el documento de la tasación, se puede tener una idea de donde pudo estar situado el lienzo en su casa. En lo que podría haber sido el mismo ámbito descrito en el inventario, colgaban además nueve mapas grandes, un paisaje de gran tamaño, cuatro lienzos de las Cuatro Estaciones, retratos de la familia real y un retrato del humanista Justo Lipsio ${ }^{51}$. Entre esas obras no quedaría en absoluto fuera de lugar un lienzo dedicado al dueño de la casa, que ejercía también una labor de magisterio, representando dentro de la más absoluta modernidad a un filósofo y pedagogo brillante, Diógenes. Velázquez había ido tomando de la vida de Laercio, pero también de su personal conocimiento del mundo, elementos para formar su imagen, para representar al filósofo del modo más completo, su personalidad, su vida, sus enseñanzas y su labor de maestro, que lo enlazaran, además, con las ideas y con la actividad de su patrono, Fonseca.

Meditaría sin duda el canónigo ante el cuadro y ante las profundas enseñanzas que encerraba, sugeridas unas y expresadas otras por la mano genial de su joven protegido; él, amigo del conde-duque de Olivares, el Sumiller de la cortina del rey, bien cercano a los poderosos, que murió endeudado y con su casa llena de riquezas y vanas glorias mundanas. Cuando Fonseca, también en su testamento, enfermo de muerte, dio las instrucciones para su entierro, ordenó, sin embargo, que se depositase su «cuerpo en el combento de carmelitas descalzas...y sea de noche, sin pompa ni ostentación ninguna y despues sea trasladado a donde pareciere a mis testamentarios» ${ }^{52}$. Laercio, narraba así la muerte de Dió-

48 Francisco Pacheco, op. cit. (ed. 1991), p. 203. Es de interés la referencia del suegro de Velázquez al canónigo en la primera visita del artista a Madrid, en 1622: «Fue muy agasajado de los dos hermanos don Luis y don Melchior del Alcázar, y en particular de don Juan de Fonseca, sumiller de cortina de Su Majestad (aficionado a su pintura)». Lo que parece indicar que si ya en ese tiempo Fonseca era aficionado a la pintura de Velázquez tal vez tuviera ya en su poder El Aguador. Es en el segundo viaje a Madrid, en 1623, cuando Velázquez pinta a su protector: "hospedóse en su casa, donde fue regalado y servido, y hizo su retrato».

${ }^{49}$ No existieron ediciones españolas contemporáneas de las Vidas de Laercio (véase nota 32), aunque Velázquez pudo servirse de las ediciones en italiano o francés, así como de traducciones parciales manuscritas, frecuentes en la época. Pudo asimismo valerse de ayudas de amigos humanistas, como recomendaba Pacheco: «...inquirir por los libros y por varones doctos muchas cosas para las noticias de la verdad y puntualidad de fábulas o historias», op. cit., (ed. 1991), pp. 284-286.

so José López Navío, op. cit. 1961, p. 69.

51 José López Navio, op. cit. 1961, p.79. Obras de carácter laico.

52 José López Navío, op, cit. 1961, p. 72. 
genes: «Dicen algunos que en su muerte mandó arrojasen su cadáver sin darle sepultura, para que todos los animales participasen de él; o bien lo metiesen en un hoyo, cubriéndolo con un poco de polvo».

El siglo XVII tenía bien presentes a los clásicos, pero ese sofisticado asunto de enrevesado título, Diógenes enseñando a los hijos de Xeníades, no va a terminar con el claro y directo de El'Aguador (que no El Aguador de Sevilla). «Aguador» fue en definitiva Diógenes y como tal lo quiso mantener el propio Velázquez para el futuro, ocultando el elevado tema, pensado sólo para intelectuales, a los ojos ignorantes de los escribanos de su tiempo. 